\title{
Penerapan Historical Approach dalam Proses Pembelajaran Pancasila di Perguruan Tinggi
}

\author{
Irvan Tasnur ${ }^{1}$, Mustamin ${ }^{2}$, Fitra Widya Wati ${ }^{3}$ \\ ${ }^{1}$ PPs Pendidikan Sejarah, Universitas Negeri Yogyakarta \\ Email: irvantasnur@gmail.com \\ ${ }^{2}$ PPs Pendidikan Sejarah, Universitas Negeri Yogyakarta \\ Email : mustaminuny@gmail.com \\ ${ }^{3}$ Program Studi Pendidikan Sejarah, Universitas Negeri Makassar \\ Email: widyafitrah@gmail.com
}

\begin{abstract}
The purpose of this study is to explore the process, response and impact of the planting of Pancasila values through the application of the historical approach in tertiary institutions. The method used in this study is qualitative where the process of collecting data is done by observation, interviews and documentation whose results are then analyzed using interactive model analysis. The results found that the process of planting the value of Pancasila at Yogyakarta State University was carried out in several stages consisting of receiving, responding, valuing, organization, characterization. In the first two stages of lecturer competence is the main factor influencing the success of the process, while for the last three stages the role of students becomes very dominant as a determinant of success because the process cannot be intervened by a lecturer. The application of the historical approach in the learning process of Pancasila at Yogyakarta State University received a very positive response from students. to keep thinking critically. Based on the results of the study it was also found that the application of the historical approach had a positive impact on improving students' cognitive thinking, this was evidenced from the results of an evaluation of 60 students who took Pancasila courses in which of the total students who took the course there were $90 \%$ of students who could answer correctly various theoretical questions related to Pancasila and $100 \%$ of students can answer various contemporary problems by using the values contained in Pancasila. Also, the application of this approach has a positive impact on affective values in students as reflected in increased discipline and high mutual respect in differences and also has a good effect on psychomotor improvement, which is indicated by the increase in students' communication skills in the discussion process.
\end{abstract}

Keywords : Values, Approaches, History, Pancasila

Abstrak.Tujuan penelitian ini adalah untuk menggali proses, respon serta dampak penanaman nilai-nilai pancasila melalui penerapan historical approach di perguruan tinggi. Metode yang digunakan dalam penelitian ini adalah kualitatif dimana proses pengumpulan data dilakukan dengan observasi, wawancara dan dokumentasi yang hasilnya kemudian dianalisis menggunakan analisis model interaktif. Hasil penelitian ditemukan bahwa proses penanaman nilai pancasila di Universitas Negeri Yogyakarta dilakukan dalam beberapa tahapan yang terdiri dari receiving, responding, valuing, organization, characterization. Pada dua tahapan awal kompetensi dosen merupakan faktor utama yang mempengaruhi keberhasilan proses tersebut, sedangkan untuk tiga tahapan terakhir peran mahasiswa menjadi sangat dominan sebagai penentu keberhasilan karena proses tersebut tidak dapat diintervensi oleh seorang dosen. Penerapan pendekatan sejarah dalam proses pembelajaran pancasila di Universitas Negeri Yogyakarta mendapatkan respon yang sangat positif dari mahasiswa hal ini disebabkan oleh beberapa faktor yaitu kemampuan dosen dalam menyampaikan peristiwa sejarah dan kontemporer yang nantinya dikaitkan dengan nilai pancasila, penggunaan media kekinian, serta tidak dibatasinya ruang gerak mahasiswa untuk tetap berpikir kritis. Berdasarkan hasil penelitian pula didapatkan bahwa penerapan historical approach berdampak positif bagi peningkatan daya berpikir kognitif mahasiswa, hal ini dibuktikan dari hasil evaluasi terhadap 60 mahasiswa yang mengikuti mata kuliah pancasila dimana dari total keseluruhan mahasiswa yang mengikuti mata kuliah 
tersebut terdapat $90 \%$ orang mahasiswa yang dapat menjawab dengan benar berbagai pertanyaan yang bersifat teoritis terkait pancasila dan $100 \%$ mahasiswa dapat menjawab berbagai permasalahan kontemporer dengan menggunakan nilai-nilai yang terkandung dalam pancasila. Selain itu, penerapan pendekatan tersebut juga berdampak positif terhadap nilai afektif dalam diri mahasiswa yang tercermin dari peningkatan kedisiplinan dan tingginya rasa saling menghormati di tengah perbedaan, dan juga berpengaruh baik terhadap peningkatan psikomotorik yang ditunjukkan dari meningkatnya kemampuan berkomunikasi mahasiswa dalam proses diskusi.

Kata Kunci : Nilai, Pendekatan, Sejarah, Pancasila

\section{PENDAHULUAN}

Indonesia merupakan negara kepulauan terluas di dunia, luas negara ini setara dengan tujuh negara Eropa apabila digabungkan menjadi satu. Dengan jumlah luas wilayah ini, Indonesia dihuni oleh kurang lebih 260 juta penduduk, dengan 1340 suku bangsa, 742 bahasa daerah dan 6 agama besar serta 187 kepercayaanpenghayatan atau agama lokal (Ghafarie, 2018). Heterogenitas yang sangat kompleks merupakan peluang dan juga tantangan Indonesia sebagai negara kepulauan. Salah satu tantangan yang di hadapi oleh masyarakat indonesia pada akhir-akhir ini adalah yang terkait dengan problematika kebangsaan baik skalanya yang bersifat mikro seperti kenakalan remaja, hingga yang lebih besar lagi seperti lunturnya nilai budaya yang mengarah pada proses disintegrasi nasional. Tentunya permasalahan tersebut harus segera diselesaikan dan jalan atau metode yang harus dilakukan yaitu dengan menanamkan nilai-nilai karakter yang telah termaktub dalam pancasila.

Pancasila lahir dari hasil refleksi mendalam terhadap kondisi sosio, kultural dan historis masyarakat indonesia yang mengandung nilai-nilai kebaikan dan menjadi jati diri bangsa Indonesia (Darmadi, 2019). Sebagai dasar negara, pancasila mempunyai lima nilai utama yang mengatur tatanan hidup rakyat indonesia di segala lini kehidupan yang meliputi sektor ekonomi, sosial, politik, pemerintahan dan sebagainya(Gesmi \& Yun, 2018), maka dari itu nilai-nilai tersebut dapat digunakan sebagai solusi (counter discourse) terhadap berbagai permasalahan yang dihadapi oleh bangsa Indonesia. Penanaman nilai pancasila dalam realitasnya telah mulai ditanamkan melalui pengajaran formal yang dilakukan pada jenjang pendidikan terendah yaitu pada taman kanak-kanak (TK) nanahingga pada tingkatan perguruan tinggi(Nani, 2009). Namun, usaha tersebut masih belum optimal dan menemui beberapa kendala, hal ini dapat dibuktikan dengan masih maraknya prilaku kenakalan remaja yang terjadi, kesulitan proses internalisasi ini bukan hanya dialami pada jenjang pendidikan rendah hingga menengah akan tetapi juga dialami pada jenjang perguruan tinggi akibat daya kritis pada jenjang ini jauh lebih tinggi atau dapat dikatakan telah mencapai puncaknya.

Daya kritis mahasiswa sering dikaitkan dengan sulitnya menginternalisasi nilai-nilai pancasila di perguruan tinggi, tentunya anggapan ini sangat tidak berdasar karenasalah satu tujuan pendidikan adalah mengasah kemampuan pedagogik kritis dalam diri mahasiswa(Wijanarko, 2005). Sikap kritis mahasiswa adalah peluang dalam proses internalisasi nilai pancasila (Bali, 2013)sehingga pendekatan dalam proses pembelajarannya sebaiknya bukan hanya menggunakan pendekatan teoritis dengan mempelajari falsafah yang ada didalamnya dan mengarah pada proses indoktrinasi akan tetapi juga memberikan contoh nyata dalam kehidupan sehari-hari sehingga pemenuhan unsur pembuktian terhadap berbagai nilai dapat diterima secara empiris oleh mahasiswa. Berdasarkan pertimbangan tersebut, Universitas Negeri Yogyakarta melakukan suatu inovasi pembelajaran dalam rangka menginternalisasi nilai-nilai pancasila ke dalam diri mahasiswa menggunakan pendekatan historical approach dengan tujuan agar mahasiswa dapat belajar dan mendapatkan contoh empiris dari peristiwa masa lalau sehingga dapat diterima oleh pemikiran-pemikiran kritis yang ada dalam diri seorang mahasiswa.

Pemilihan pendekatan sejarah atau historical approach dalam proses internalisasi pancasila di perguruan tinggi bukanlah tanpa sebab, melainkan terdapat beberapa pertimbangan mengapa hal tersebut dilakukan, alasan-alasan tersebut dapat dirincikan sebagai berikut. Pertama, Sejarah adalah 
guru kehidupan atau lebih dikenal dengan istilah historia magistra vitae yang memiliki fungsi didaktik(Koselleck, 2004, p. 28), selanjutnya menurut Notosusanto sejarah adalah media yang sangat tepat dalam melakukan proses edukatif, instruktif, inspiratif, sehingga dapat dengan mudah menanamkan berbagai nilai yang mengajarkan kearifan dan kebijaksanaan dalam kehidupan, dan alasan terakhir adalah karena sejarah merupakan media yang sangat efektif dalam transfer of value melalui pembelajaran masa lalu, contoh yang bersifat empiris akan membuat nilai-nilai pancasila dapat dengan mudah diterima oleh mahasiswa. Maka dari itu, penelitian ini akan mencoba menjelaskan tentang bagaimana praktek penerapan pendekatan historical approach di perguruan tinggi, bagaimana respon mahasiswa dalam mempelajari mata kuliah pancasila yang menggunakan pendekatan tersebut serta dampak pembelajaran pancasila dengan menggunakan pendekatan historical approach terhadap kemampuan kognitif, afektif, psikomotorik mahasiswa.

\section{METODE PENELITIAN}

Fokus kajian dalam penelitian ini adalah mengkaji proses, respon dan dampak penerapan historical approach dalam menginternalisasi nilai-nilai pancasila di perguruan tinggi. Metode penelitian yang digunakan dalam penelitian ini adalah kualitatif dengan menggunakan pendekatan fenomenologi. Pengumpulan data dilakukan dengan tiga cara atau teknik utama yaitu observasi, wawancara tidak terstruktur dan dokumentasi, data yang telah dikumpulkan kemudian diuji kebasahan datanya melalui uji credibility, transferability, confirmability, dependability dan selanjutnya dianalisis dengan model analisis interaktif Miles dan Huberman (Sugiyono, 2014). Setelah data dianalisis, data tersebut kemudian disajikan dalam bentuk naratif deskriptif.

\section{HASIL DAN PEMBAHASAN}

\section{A. Proses Penanaman Nilai Pancasila Melalui Historical Approach}

Mata kuliah pancasila merupakan mata kuliah umum yang wajib diajarkan di seluruh jurusan di Universitas Negeri Yogyakarta. Terdapat berbagai jenis pendekatan dalam proses pembelajaran mata kuliah tersebut, Salah satu pendekatan yang dilakukan pihak universitas untuk menginternalisasikan nilai-nilai pancasila adalah dengan menggunakan historical approach. Penerapan Historical approach memiliki arti bahwa sudut pandang atau suatu titik tolak yang digunakan selama proses pembelajaran berlangsung selalu berpatokan pada peristiwa-peristiwa historis atau memperhatikan unsur sejarah di dalamnya(Prastowo, 2017, p. 239). Langkah pertama yang dilakukan oleh pihak untuk menerapkan pendekatan historical approach adalah degan memilih dosen yang kompeten dalam bidang kajian sejarah khususnya sejarah Indonesia serta menguasai pula akar sejarah dan nilai-nilai pancasila. Pemilihan dosen sejarah tersebut bukanlah suatu alasan yang tidak mendasar, karena salah satu faktor keberhasilan dari suatu proses pembelajaran ditentukan oleh sosok tenaga pendidik atau seorang dosen (Widoyoko, 2009, p. 1), hal tersebut kembali dipertegas dengan adanya hasil penelitian yang dilakukan oleh Heyneman \& Loxley (1983, p. 1662) terhadap 16 negara berkembang yang menemukan bahwa dari sekian banyak input dalam pendidikan, sosok sorang guru/dosen merupakan penentu utama keberhasilan pencapaian tujuan pendidikan yang ada.

Berdasarkan hasil observasi yang dilakukan pada dua kelas yang berbeda penanaman nilai pancasila menggunakan historical approach dilakukan dosen dengan beberapa tahapan yaitu pemberian contoh dan materi, berdiskusi, menilai, mengorganisasikan dan pembentukan karakter. Model penanaman nilai tersebut apabila ditelaah merupakan penerapan dari model yang dikembangkan oleh Krathwohl $(1964$, p. 35) yang terdiri atas lima proses utama yaitu receiving, responding, valuing, organization dan characterization. Bila dianalisis lebih mendalam terkait tahapan yang dilakukan tersebut maka ditarik kesimpulan bahwa historical approach merupakan suatu pendekatan yang berpusat pada siswa atau student centered approaches karena peran mahasiswa sangat besar dalam menentukan tercapainya tujuan pembelajaran, walaupun tidak dapat pula dipungkiri bahwa seorang dosen merupakan fasilitator yang wajib tersedia agar dapat 
mencapai hal tersebut. Berdasarkan hasil wawancara yang dilakukan kepada dosen, pemilihan model yang dikemukakan oleh Krathwohl disebabkan oleh langka-langka yang terdapat dalam model tersebut tidak menutup ruang gerak bagi mahasiswa untuk tetap berpikir kritis dalam proses pembelajaran Pancasila yang sedang berlangsung, sehingga daya analisis, kritis dan motivasi belajar mahasiswa tetap dapat dikembangkan.

Pada tahapan awal atau receiving seorang dosen memberikan contoh yang baik berupa tindakan dan prilaku yang mencerminkan nilai pancasila, seperti mengucapkan salam dengan beberapa salam keagamaan lalu kemudian memulai proses pembelajaran dengan mengangkat sebuah kisah sejarah dengan gaya storytelling dan disertai dengan ilustrasi gambar. Pemberian contoh tersebut merupakan suatu langka yang tepat mengingat bahwa salah satu media yang efektif dalam proses penanaman nilai adalah pemberian contoh (Wardani, 2015), dalam hal ini seorang dosen memberikan contoh berupa tindakan dan contoh yang bersumber dari peristiwa sejarah, seperti usaha yang dilakukan untuk menanamkan nilai kejujuran dan persamaan di mata hukum, pendidik berusaha menceritakan kisah Roeslan Abdul Ghani yang merupakan menteri luar negeri Indonesia dan pernah dipenjara selama dua bulan akibat membawa uang titipan seseorang sebesar 1500 US\$ dari luar negeri karena adanya aturan yang melarang membawa uang lebih dari 1000 US\$ ke dalam maupun keluar dari Indonesia akibat adanya inflasi yang sangat besar. Pengangkatan kisah inspiratif tentang bersihnya penegakan hukum tersebut merupakan suatu suntikan positif ke dalam diri mahasiswa agar senantiasa berusaha berbuat jujur dan taat terhadap hukum sesuai dengan nilai-nilai pancasila yang berlaku.

Berdasarkan hasil pengamatan yang dilakukan pada tiap-tiap pertemuan dosen selalu menyertakan kisah inspiratif sejarah atau sebuah peristiwa kontemporer yang nantinya dihubungkaitkan dengan peristiwa sejarah masa lalu dan nilai-nilai pancasila. Setelah menceritakan hal tersebut maka terdapat usaha dosen untuk merelevansikan peristiwa yang ada dengan nilai-nilai pancasila, sebagai contoh peristiwa yang bersifat kontemporer adalah viralnya Agnes Monica yang menyatakan dirinya sebagai keturunan Jepang, Cina dan Jerman, diangkatnya kisah tersebut kemudian disertai gambar screenshot kolom komentar Instagram mengenai pemberitaan ini membuat daya tarik mahasiswa terpusat pada materi yang sedang dibawakan, langkah selanjutnya yang dilakukan adalah berusaha untuk merekonstruksi pemahaman tentang asal usul nenek moyang bangsa Indonesia menggunakan pendekatan sejarah baik itu berdasarkan penemuan benda, bentuk fisik, bahasa dan genealogi dan pada akhirnya ditemukan bahwa nenek moyang Indonesia merupakan perpaduan antara beberapa ras yang berbeda dan datang dari beberapa kepulauan besar lainnya sehingga dapat disimpulkan bahwa orang indonesia adalah mereka yang bermukim dan menetap di Indonesia dan memiliki kecintaan yang besar terhadap tanah air tanpa memandang status ras, agama, warna kulit dan budaya. Ketika mahasiswa tidak melepaskan perhatiannya terhadap cerita tersebut maka seorang dosen kemudian berusaha merelevansikannya dengan nilai persatuan yang terdapat dalam ideologi pancasila.

Tahapan berikutnya adalah responding, berdasarkan hasil observasi yang telah dilakukan tahapan ini berlangsung sebanyak tiga kali yaitu diawal, di tengah dan di akhir proses pembelajaran. Seringnya dosen menghubung-kaitkan antara peristiwa kontemporer, sejarah dan nilai pancasila menyebabkan terjadinya proses diskusi yang panjang antar mahasiswa dalam bentuk individu maupun kelompok, pada tahapan ini dosen memposisikan dirinya hanya sebagai moderator untuk memfasilitasi perdebatan yang terjadi. Tujuan penggunaan metode diskusi ini adalah seusai dengan pendapat yang dikemukan oleh Tjokrodiharjo(2000, p. 3) bahwa tujuan diskusi adalah untuk meningkatkan daya berfikir kritis, menumbuhkan keaktifan mahasiswa dan dapat membantu mahasiswa dalam mempelajari cara berpikir kritis, logis dan kronologis. Setelah perdebatan berlangsung lama, maka diambil sebuah tindakan penengah dan menjelaskan kembali tentang masalah yang dibicarakan dengan menggunakan pendekatan sejarah dan biasanya disertai dengan berbagai contoh.Setelah perdebatan usai masing-masing mahasiswa mendapatkan kesempatan untuk menilai apakah permasalahan yang dibicarakan bertentang atau telah sesuai dengan nilainilai pancasila yang ada, pada tahapan ini dosen sudah tidak dapat terlibat dan mempengaruhi 
pemikiran dari masing-masing mahasiswa. Pada tahapan ini pul mahasiswa juga akan menentukan atau menilai dengan pertimbangan dari paradigma masing-masing secara logis tentang apakah nilai pancasila sesuai dengan nilai budaya dan tujuan historis penciptaannya dan menentukan apakah nilai pancasila tersebut layak untuk dijalankan atau diterapkan dalam kehidupan sehari-hari. Setelah menilai tahapan selanjutnya adalah organization tahapan ini dilakukan oleh mahasiswa dengan mengorganisasikan atau menyusun nilai-nilai pancasila ke dalam beberapa bagian yang nantinya akan diterapkan dalam kehidupan sehari-hari. Tahapan akhir dari proses penanaman nilai melalui pendekatan historical approach adalah characterization dimana tahapan ini dilakukan secara sadar maupun tidak sadar oleh mahasiswa dan sangat bergantung pada kebiasaan yang diulang secara teratur dan terus menerus, apabila seorang mahasiswa melakukan tindakan yang berulang seperti menghormati pendapat orang lain ketika bersilang pendapat terkait peristiwa sejarah yang berhubungan dengan nilai pancasila maka karakter tersebut akan terbentuk dengan sendirinya.

Berdasarkan beberapa tahapan diatas maka dapat ditarik suatu kesimpulan bahwa dosen memiliki peran yang sangat penting dalam proses internalisasi nilai-nilai pancasila terutama pada dua tahapan awal maka dari itu tuntutan akan pemahaman yang luas baik itu dalam kajian sejarah maupun tren yang bersifat kontemporer adalah suatu kompetisi yang wajib dipenuhi apabila ingin menerapkan historical approach dalam proses penanaman nilai tersebut. Pada tiga tahapan akhir peranan mahasiswa menjadi faktor utama dalam menentukan keberhasilan penerapan historical Approach, faktor tersebut yaitu terdiri dari faktor internal seperti fisiologis (kesehatan) dan psikologis (intelegensi, minat, bakat, motivasi dan cara belajar) (Usman \& Setiawati, 1993, p. 8). Apabila faktor tersebut terpenuhi maka usaha dosen dalam menanamkan nilai-nilai pancasila melalui historical approach akan dapat berjalan dengan baik dan mencapai tujuannya, selain faktor yang telah disebutkan diatas kondisi lingkungan dan keluarga juga mendukung proses penanaman nilai tersebut karena dalam masing-masing kelompok masyarakat dan keluarga mempunyai nilainilai tersendiri yang harus di junjung tinggi, apabila nilai tersebut sejalan dengan nilai-nilai pancasila maka penanaman nilai dapat berhasil secara efektif, namun mengingat pancasila merupakan abstraksi dari akar budaya masyarakat indonesia yang beragam maka dapat disimpulkan bahwa nilai yang terdapat dalam kelompok tersebut dapat mendukung penanaman nilai-nilai pancasila.

\section{B. Respon Terhadap Penggunaan Historical Approach}

Pendekatan sejarah yang digunakan dalam mengajarkan mata kuliah pancasila ditambah lagi dengan diangkatnya isu-isu populer membuat mahasiswa menikmati proses pembelajaran yang berlangsung. Selama observasi dilakukan terhadap dua kelas yang berbeda dalam kurun waktu empat kali pertemuan atau satu bulan lamanya, antusiasme atau minat belajar mahasiswa mengalami peningkatan yang sangat drastis, hal tersebut dapat disaksikan dengan aktifnya mahasiswa dalam sesi tanya jawab. Isu yang diangkatpun dalam sesi tersebut merupakan isu kesejarahan atau isu kontemporer yang masih berkaitan dengan sejarah dan pancasila seperti kasus korupsi, konflik SARA, hukum dan lain sebagainya. Tingginya minat belajar mahasiswa juga merupakan pertanda meningkatnya empat indikator yang dapat mengukur minat belajar yaitu ketertarikan untuk belajar, perhatian dalam belajar, motivasi belajar dan pengetahuan (Nurhasanah \& Sobandi, 2016, p. 130), artinya apabila seluruh indikator mengalami peningkatan maka hasil belajar mahasiswa akan sangat baik atau dapat mencapai tujuan dari proses pembelajaran. Kemampuan dosen untuk merangsang daya kritis mahasiswa merupakan faktor penting yang menjadi penggerak utama dalam menciptakan suasana akademis tersebut.Antusiasme juga timbul dikarenakan oleh penggunaan media yang menarik seperti gambar yang bersumber dari Instagram terkait masalah yang sedang dikaji.

Berdasarkan hasil wawancara yang dilakukan terhadap beberapa narasumber, menariknya proses pembelajaran berlangsung disebabkan oleh beberapa hal seperti penggunaan media kekinian, kemampuan dan gaya bahasa yang digunakan oleh dosen serta diangkatnya kisah sejarah yang dikomparasikan dengan masalah kontemporer dan nila-nilai pancasila. Pemberian contoh yang bersifat empiris dari peristiwa sejarah dan kekinian menjadi nilai tambah yang menyebabkan 
mahasiswa semakin tertarik mempelajari nilai pancasila, hal tersebut sesuai dengan fungsi sejarah sebagaimana yang diungkapkan oleh Rowse (2014) bahwa "sejarah adalah sekolah akal sehat" artinya nilai dapat ditanamkan melalui penelusuran kembali terhadap kejadian-kejadian masa lalu. Pemberian ruang kepada mahasiswa untuk mengkritisi dan menilai suatu masalah tanpa adanya proses pemaksaan atau tekanan juga menjadi faktor lain tingginya minat mahasiswa untuk mengikuti proses pembelajaran dari awal hingga akhir, pemberian ruang terhadap daya kritis merupakan upaya yang tepat dalam menjaga "motivasi baik" dalam diri mahasiswa untuk terus belajar guna mencapai tujuan yang diinginkan (Zanthy, 2016). Berdasarkan beberapa uraian yang telah dijelaskan sebelumnya maka dapat ditarik sebuah kesimpulan bahwa penerapan historical approach dalam proses penanaman nilai-nilai pancasila menyebabkan timbulnya daya kritis mahasiswa dan berpengaruh terhadap meningkatnya motivasi belajar, namun hal tersebut baru dapat terjadi apabila dosen memiliki kompetensi yang baik dalam mengelola dan memadupadankan peristiwa sejarah, isu kontemporer dan nilai-nilai pancasila serta memilih media yang pas dalam mengilustrasikan masalah yang sedang dikaji.

\section{Dampak Penerapan Historical Approach}

Telah dijelaskan diawal bahwa penerapan pendekatan sejarah disambut dengan positif oleh mahasiswa, berdasarkan hasil observasi yang telah dilakukan penerapan pendekatan tersebut mempengaruhi perkembangan kognitif, afektif dan psikomotorik mahasiswa. Kemampuan kognitif adalah kemampuan yang dimiliki oleh seseorang dalam hal berpikir, menentukan tujuan, menyusun rencana, menyusun visi untuk mencapai tujuan yang diinginkan (Waruwu, 2010, p. 47). Perkembangan dalam bidang kognitif sebagai dampak penerapan historical approach dapat dilihat dari semakin kritisnya mahasiswa terhadap berbagai permasalahan kontemporer yang terkait dengan kesesuaiannya dengan nilai-nilai pancasila di Indonesia, sifat kritis merupakan pertanda baik bagi meningkatnya motivasi untuk terus belajar atau menggali pengetahuan baru terutama yang berkaitan dengan nilai-nilai pancasila. Berdasarkan apa yang telah diamati di lapangan tingkat kognitif yang dimiliki mahasiswa akibat penerapan pendekatan sejarah apabila disesuaikan dengan taxonomy Blomm (David R. Krathwohl, Benjamin S. Bloom, 1964) maka tingkat pemahaman mahasiswa telah mencapai grade C5 atau evaluate. Pencapaian tersebut menandakan bahwa mahasiswa telah dapat menilai sendiri beberapa problematika yang bersifat kontemporer yang berarti bahwa daya pikir mahasiswa telah dekat pada tingkatan tertinggi dari pengetahuan manusia yaitu proses menciptakan atau create. Selain itu, berdasarkan hasil wawancara yang dilakukan seringnya seorang dosen menyampaikan kisah-kisah inspiratif toko-toko sejarah sebagai contoh empiris penerapan nilai pancasila membuat mahasiswa terinspirasi dan termotivasi sehingga keinginan belajar mereka semakin tinggi. Hal tersebut menjadi penyebab meningkatnya nilai kognitif mahasiswa yang dapat dilihat dari hasil evaluasi terhadap 60 mahasiswa yang mengikuti mata kuliah pancasila dimana dari total keseluruhan tersebut terdapat sebanyak $90 \%$ mahasiswa dapat menjawab dengan benar berbagai pertanyaan yang bersifat teoritis terkait pancasila dan $100 \%$ mahasiswa dapat memberi solusi berbagai permasalahan kontemporer dengan menggunakan nilai-nilai yang terkandung dalam pancasila. Maka dari itu, dapat disimpulkan bahwa penerapan historical approach berdampak positif terhadap peningkatan akademik mahasiswa.

Penerapan historical approach juga berdampak baik terhadap kepribadian atau afektif mahasiswa, afektif sering juga disebut sebagai minat atau sikap untuk terus melakukan kebaikan (Nugraheni, Mulyani, \& Ariani, 2013, pp. 37-39). Peningkatan afektif mahasiswa sebagai dampak penerapan historical approach dapat disaksikan tingkat kehadiran mahasiswa di kelas yang sangat tinggi, artinya penerapan pendekatan tersebut mampu menciptakan rasa disiplin yang tinggi. Selain itu, penerapan pendekatan ini juga berpengaruh pada semakin etisnya atau beradabnya cara berkomunikasi mahasiswa baik dalam bertanya, menanggapi ataupun memberikan saran dan jawaban, hal ini dapat dilihat dalam proses diskusi yang telah berlangsung dimana masing-masing mahasiswa yang bersilang pendapat tidak saling menjatuhkan antara satu dan yang lainnya dan hal ini menggambarkan suatu praksis dari rasa saling menghargai untuk menjaga persatuan dan 
kesatuan. Apabila dimasukkan dalam taxonomy Anderson maka tindakan atau sikap mahasiswa yang berhasil diamati tersebut telah masuk dalam puncak pendidikan karakter yaitu characterization atau telah menjadi karakter.Penerapan pendekatan historical approach juga mempengaruhi kemampuan psikomotorik mahasiswa dimana penggunaan pendekatan tersebut berdampak pada meningkatnya kemampuan dalam berkomunikasi, kemampuan memecahkan masalah dan mengembangkan solusi yang baik pada diri mahasiswa. Apabila memperhatikan hal tersebut maka kemampuan psikomotorik pada diri mahasiswa berdasarkan taxonomy davetelah sampai pada tingkat articulation atau kemampuan mengadaptasi dan mengintegrasikan nilai atau dibawah setingkat dari puncak kemampuan psikomotorik manusia.

\section{KESIMPULAN}

Berdasarkan uraian yang telah disampaikan sebelumnya maka dapat ditarik tiga kesimpulan utama terkait penerapan historical approach dalam menanamkan nilai pancasila di perguruan tinggi. Pertama, proses penanaman pancasila di perguruan tinggi dapat dilakukan dengan beberapa tahapan utama yang terdiri dari receiving, responding, valuing, organization, characterization, kesuksesan dua tahapan awal yaitu receiving dan responding ditentukan oleh kompetensi yang dimiliki seorang dosen terutama dalam hal penguasaan kesejarahan sedangkan untuk kesuksesan tiga tahapan berikutnya ditentukan dari kemampuan mahasiswa. Kedua, penerapan historical approach mendapatkan respon yang sangat positif dari mahasiswa, hal tersebut dibuktikan dengan hidupnya suasana kelas terutama dalam proses diskusi terkait berbagai permasalahan yang terkait dengan ideologi pancasila. Terakhir, penerapan historical approach berdampak positif terhadap kemampuan kognitif yang ditunjukkan dari hasil tes pemahaman mahasiswa terhadap nilai-nilai pancasila, selain itu penerapan pendekatan tersebut juga berdampak pada meningkatnya kedisiplinan dan rasa saling menghargai antar mahasiswa dan juga meningkatnya kemampuan komunikasi mahasiswa dalam proses diskusi atau tanya jawab.

\section{DAFTAR PUSTAKA}

Bali, M. M. (2013). Peran Dosen Dalam Mengembangkan Karakter Mahasiswa. Humaniora, 4(2), 800810.

Darmadi, H. (2019). Pengantar Pendidikan Era Globalisasi: Konsep Dasar, Teori, Strategi dan Implementasi dalam Pendidikan Globalisasi. Jakarta: An1mage.

David R. Krathwohl, Benjamin S. Bloom, B. B. M. (1964). Taxonomy Of Educational Objectives Handbook II: Affective Domain. New Yory: David McKay Company.

Gesmi, I., \& Yun, H. (2018). Buku Ajar Pendidikan Pancasila. Uwais Inspirasi Indonesia.

Ghafarie, I. (2018). Meyakini Menghargai: Ensiklopedia Agama-Agama. Expose.

Heyneman, S. P., \& Loxley, W. A. (1983). The Effect Of Primary-School Quality On Academic Achievement Across Twenty-Nine High-And Low-Income Countries. American Journal of Sociology, 88(6), 1162-1194.

Koselleck, R. (2004). Futures Past: On The Semantics Of Historical Time. New York: Columbia University Press.

Nani, Y. C. (2009). Menanamkan Nilai Pancasila pada Anak Sejak Usia Dini. Humanika: Kajian Ilmiah Mata Kuliah Umum, 9(1).

Nugraheni, D., Mulyani, S., \& Ariani, S. R. D. (2013). Pengaruh Pembelajaran Bervisi Dan Berpendekatan SETS Terhadap Prestasi Belajar Ditinjau dari Kemampuan Berpikir Kritis Siswa Kelas X SMAN 2 Sukoharjo Pada Materi Minyak Bumi Tahun Pelajaran 2011/2012. Jurnal Pendidikan Kimia, 2(3), 34-41.

Nurhasanah, S., \& Sobandi, A. (2016). Minat Belajar Sebagai Determinan Hasil Belajar Siswa. Jurnal Pendidikan Manajemen Perkantoran, 1(1), 128-135.

Prastowo, A. (2017). Menyusun Rencana Pelaksanaan Pembelajaran (RPP) Tematik Terpadu. Kencana. 
Rowse, A. L. (2014). Apa Guna Sejarah. Depok: Komunitas Bambu.

Sugiyono. (2014). Metode Penelitian Kuantitatif, Kualitatif, dan R\&D. Bandung: Alfabeta.

Tjokrodiharjo, S. (2000). Diskusi Kelas (Bagian 1). Surabaya: Unesa.

Usman, U., \& Setiawati, L. (1993). Upaya Optimalisasi Kegiatan Belajar Mengajar. Bandung: Remaja Rosdakarya.

Wardani, N. S. (2015). Pengembangan Nilai-Nilai Budaya Sekolah Berkarakter. Scholaria: Jurnal Pendidikan Dan Kebudayaan, 5(3), 12-22.

Waruwu, F. E. (2010). Membangun Budaya Berbasis Nilai. Kanisius.

Widoyoko, E. P. (2009). Analisis Pengaruh Kinerja Guru Terhadap Motivasi Belajar Siswa. Jurnal Pendidikan Umpwr, 1-16.

Wijanarko, J. (2005). Mendidik Anak: Untuk Meningkatkan Kecerdasan Emosional Dan Spiritual. Jakarta: Gramedia Pustaka Utama.

Zanthy, L. S. (2016). Pengaruh Motivasi Belajar Ditinjau dari Latar Belakang Pilihan Jurusan Terhadap Kemampuan Berpikir Kritis Mahasiswa di STKIP Siliwangi Bandung. Teorema: Teori Dan Riset Matematika, 1(1), 47-54. 